\title{
An Official Journal of
} International Union of Nutritional Sciences (IUNS)

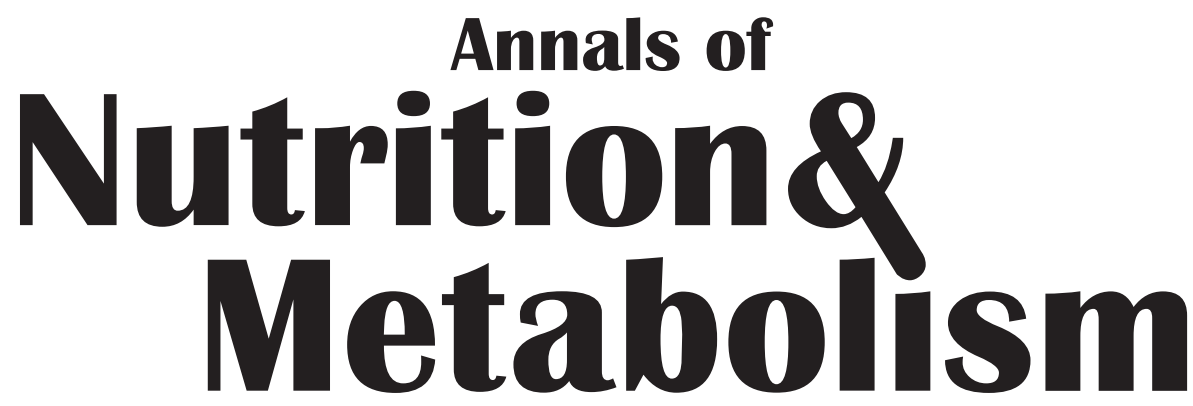

Journal of Nutrition, Metabolic Diseases and Dietetics

Founded 1959 as 'Nutritio et Dieta' by E. Azerad, H. Kapp and J. Trémolières Continued by A. Wretlind (1961-1969)

Continued by N. Zöllner (1970-1990) as 'Nutrition and Metabolism' (1970-1980), since 1980 integrating 'Annales de la Nutrition et de l'Alimentation', continued as 'Annals of Nutrition and Metabolism' Continued by G. Wolfram (1991-1999)

\section{Editor}

I. Elmadfa, Vienna

\section{Assistant Editors}

A.L. Meyer, Vienna

P. Rust, Vienna

\section{Editorial Board}

F. Azizi, Tehran

A. Berg, Freiburg

F. Branca, Rome

R. Brigelius-Flohé, Nuthetal

P.C. Calder, Southampton

N. Chang, Seoul

T. Decsi, Pécs

K. Eder, Halle/Saale

A. El-Sohemy, Toronto, Ont.

H. Goldenberg, Vienna

H. Hauner, Munich

S. Hercberg, Paris

H. Heseker, Paderborn

N. Houalla, Beirut

A. Kafatos, Heraklion

M.-H. Kang, Daejeon

E.T. Kennedy, Boston, Mass.

M. Krawinkel, Giessen

G. Krejs, Graz

A.V. Kurpad, Bangalore

W. Langhans, Zurich

M. Lawrence, Burwood, Vic.

X. Lin, Shanghai

J. Linseisen, Heidelberg
J.A. Martinez, Pamplona

H.Y. Paik, Seoul

M. Panagiotidis, Reno, Nev.

J.M. Pettifor, Johannesburg

L.A. Réthy, Budapest

G. Rimbach, Kiel

J. Sabaté, Loma Linda, Calif.

W.H.M. Saris, Maastricht

L. Serra-Majem,

Las Palmas de Gran Canaria

A.P. Simopoulos, Washington, D.C.

P. Stehle, Bonn

J.J. Strain, Coleraine

I. Thorsdottir, Reykjavik

K. Tontisirin, Nakhon Pathom

R. Uauy, Santiago

H. Vannucchi, Ribeirão Preto

A. von Rücker, Bonn

M. Wahlqvist, Clayton

W. Waldhäusl, Vienna

E. Wasantwisut, Salaya

B. Watzl, Karlsruhe

W.M. Windisch, Vienna

T. Yoshikawa, Kyoto

J. Zempleni, Lincoln, Nebr.

A. Zittermann, Bad Oeynhausen 
S. Karger

Medical and Scientific Publishers

Basel $\cdot$ Freiburg $\cdot$ Paris $\cdot$ London •

New York $\cdot$ Bangalore $\cdot$ Bangkok $•$

Shanghai $\cdot$ Singapore $\cdot$ Tokyo $\cdot$ Sydney
Disclaimer

The statements, opinions and data contained in this publication are solely those of the individual authors and contributor and not of the publisher and the editor(s). The appearance of advertisements in the journal is not a warranty, endorsement, or approval of the products or services advertised or of their effectiveness, quality or safety. The publisher and the editor(s) disclaim responsibility for any injury to persons or property resulting from any ideas, methods, instructions or products referred to in the content or advertisements.

Drug Dosage

The authors and the publisher have exerted every effort to ensure that drug selection and dosage set forth in this text are in accord with current recommendations and practice at the time of publication. However, in view of ongoing research, changes in government regulations, and the constant flow of information relating to drug therapy and drug reactions, the reader is urged to check the package insert for each drug for any change in indications and dosage and for added warnings and precautions. This is particularly important when the recommended agent is a new and/or infrequently employed drug.
All rights reserved.

No part of this publication may be translated into other languages, reproduced or utilized in any form or by any means electronic or mechanical, including photocopying, recording microcopying, or by any information storage and retrieval system, without permission in writing from the publisher or in the case of photocopying, direct payment of a specified fee to the Copyright Clearance Center (see 'General Information').

() Copyright 2008 by S. Karger AG

P.O. Box, CH-4009 Basel (Switzerland)

Printed in Switzerland

on acid-free and non-aging paper (ISO 9706) by

Reinhardt Druck, Basel

\section{KARGER}

Fax +41613061234

E-Mail karger@karger.ch

www.karger.com 


\section{Nutrition \& Metabolism}

\begin{tabular}{|c|c|}
\hline & No. 1 \\
\hline & Obituary \\
\hline II & $\begin{array}{l}\text { Steven Karger (1959-2008) } \\
\text { Karger, T. (Basel) }\end{array}$ \\
\hline & Original Papers \\
\hline 1 & $\begin{array}{l}\text { Feeding Potato Flakes Affects Cecal Short-Chain Fatty Acids, } \\
\text { Microflora and Fecal Bile Acids in Rats } \\
\text { Han, K.-H.; Hayashi, N. (Obihiro); Hashimoto, N. (Memuro); Shimada, K.; } \\
\text { Sekikawa, M. (Obihiro); Noda, T. (Memuro); Fukushima, M. (Obihiro) }\end{array}$ \\
\hline 8 & $\begin{array}{l}\text { Modulating Effects of Maternal Fish Consumption on the } \\
\text { Occurrence of Respiratory Symptoms in Early Infancy } \\
\text { Attributed to Prenatal Exposure to Fine Particles } \\
\text { Jedrychowski, W.; Flak, E.; Mroz, E.; Pac, A.; Jacek, R.; Sochacka-Tatara, E. } \\
\text { (Krakow); Spengler, J. (Boston, Mass.); Rauh, V.; Perera, F. (New York, N.Y.) }\end{array}$ \\
\hline 17 & $\begin{array}{l}\text { The Effect of Sibutramine Intake on Resting and Exercise } \\
\text { Physiological Responses } \\
\text { Rotstein, A.; Inbar, O. (Netanya); Vaisman, N. (Tel-Aviv) }\end{array}$ \\
\hline 24 & $\begin{array}{l}\text { Adipose Tissue Trans Fatty Acids and Risk of Coronary Artery } \\
\text { Disease: A Case-Control Study } \\
\text { Ghahremanpour, F.; Firoozrai, M. (Tehran); Darabi, M. (Tabriz); Zavarei, A.; } \\
\text { Mohebbi, A. (Tehran) }\end{array}$ \\
\hline 29 & $\begin{array}{l}\text { Influence of Probiotic and Conventional Yoghurt on the Status } \\
\text { of Vitamins } \mathbf{B}_{1}, \mathbf{B}_{2} \text { and } \mathbf{B}_{6} \text { in Young Healthy Women } \\
\text { Fabian, E.; Majchrzak, D.; Dieminger, B.; Meyer, E.; Elmadfa, I. (Vienna) }\end{array}$ \\
\hline 37 & $\begin{array}{l}\text { Very Low } \mathbf{n - 3} \text { Long-Chain Polyunsaturated Fatty Acid Status } \\
\text { in Austrian Vegetarians and Vegans } \\
\text { Kornsteiner, M.; Singer, I.; Elmadfa, I. (Vienna) }\end{array}$ \\
\hline 48 & $\begin{array}{l}\text { Lack of Skeletal Effect of Soy Isoflavones in Intact Growing, } \\
\text { Female Rats May Be Explained by Constant Serum Estrogenic } \\
\text { Activity despite Reduced Serum Estradiol }\end{array}$ \\
\hline & $\begin{array}{l}\text { Peterson, C.A.; Kubas, K.L.; Hartman, S.J.; Rottinghaus, G.E.; Taylor, J.A.; } \\
\text { Welshons, W.V. (Columbia, Mo.) }\end{array}$ \\
\hline 58 & $\begin{array}{l}\text { Fasting and Caloric Restriction Increases mRNA } \\
\text { Concentrations of Novel Organic Cation Transporter-2 and } \\
\text { Carnitine Concentrations in Rat Tissues } \\
\text { Luci, S.; Hirche, F.; Eder, K. (Halle/Saale) }\end{array}$ \\
\hline 68 & $\begin{array}{l}\text { Intrafamilial Associations of Lipid Profiles and the Role of } \\
\text { Nutrition: The Tehran Lipid and Glucose Study } \\
\text { Mirmiran, P.; Mirbolooki, M.; Heydarian, P.; Salehi, P.; Azizi, F. (Tehran) }\end{array}$ \\
\hline 74 & $\begin{array}{l}\text { Effect of Meal Replacement on Metabolic Risk Factors in } \\
\text { Overweight and Obese Subjects } \\
\text { König, D.; Deibert, P.; Frey, I.; Landmann, U.; Berg, A. (Freiburg) }\end{array}$ \\
\hline $\begin{array}{l}79 \\
80 \\
81\end{array}$ & $\begin{array}{l}\text { The Official FENS Calendar } \\
\text { FENS News } \\
\text { IUNS News }\end{array}$ \\
\hline
\end{tabular}

\section{No. 2}

\section{Original Papers}

83 Serum Lipids and Postprandial Glucose and Insulin Levels in Hyperlipidemic Subjects after Consumption of an Oat $\beta$-Glucan-Containing Ready Meal Biörklund, M. (Lund); Holm, J. (Bjuv); Önning, G. (Lund)

91 Effect of Nutrition Intervention on Non-Communicable Disease Risk Factors among Tehranian Adults: Tehran Lipid and Glucose Study Mirmiran, P.; Ramezankhani, A.; Hekmatdoost, A.; Azizi, F. (Tehran)

96 Meats, Processed Meats, Obesity, Weight Gain and Occurrence of Diabetes among Adults: Findings from Adventist Health Studies

Vang, A.; Singh, P.N.; Lee, J.W.; Haddad, E.H.; Brinegar, C.H (Loma Linda, Calif.)

105 Lifestyle of Hungarian Adolescents - Observations among Metropolitan Secondary School Students

Péter, S.; Regöly-Mérei, A.; Biró, L.; Nagy, K.; Arató, G.; Szabó, C.; Vámos, A.; Martos, É.; Antal, M. (Budapest)

110 Impact of a Basic Nutrition Course for Residents at a Faculty Hospital. Did It Make a Difference to Demand for Nutrition Consultations?

Kirdak, T.; Iscimen, R.; Tanir, B.; Kelebek, N.; Keskin, M.; Korun, N. (Bursa)

136 Effect of Carnitine Deprivation on Carnitine Homeostasis and Energy Metabolism in Mice with Systemic Carnitine Deficiency Knapp, A.C.; Todesco, L.; Török, M.; Beier, K.; Krähenbühl, S. (Basel)

145 Dietary Nutrients and Insulin Resistance in Urban Asian Indian Adolescents and Young Adults

Isharwal, S.; Arya, S.; Misra, A.; Wasir, J.S.; Pandey, R.M.; Rastogi, K.; Vikram, N.K.; Luthra, K.; Sharma, R. (New Delhi)

152 The Effect of Zinc Supplements in Cystic Fibrosis Patients Van Biervliet, S.; Vande Velde, S.; Van Biervliet, J.P.; Robberecht, E. (Ghent)

157 Supplementation with 200 mg/Day Docosahexaenoic Acid from Mid-Pregnancy through Lactation Improves the Docosahexaenoic Acid Status of Mothers with a Habitually Low Fish Intake and of Their Infants

Bergmann, R.L. (Berlin); Haschke-Becher, E. (Salzburg); Klassen-Wigger, P. (Vevey); Bergmann, K.E.; Richter, R.; Dudenhausen, J.W. (Berlin);

Grathwohl, D.; Haschke, F. (Vevey)

167 High Dosage of Ascorbic Acid and Alpha-Tocopherol Is Not Useful for Diminishing Oxidative Stress and DNA Damage in Healthy Elderly Adults

Retana-Ugalde, R.; Casanueva, E.; Altamirano-Lozano, M.; González-Torres, C.; Mendoza-Núñez, V.M. (Mexico City)

Abstracts

115 New Aspects in Quality and Biofunctionality of Foods First Symposium of the Vienna Research Platform of Nutrition and Food Sciences (VRPNFS)

April 25, 2008, Vienna, Austria

Guest Editors: Elmadfa, I.; Wagner, K.-H. (Vienna)

(available online only)

174 The Official FENS Calendar

175 FENS News

176 IUNS News

\section{KARGER}

Fax +41613061234

E-Mail karger@karger.ch

www.karger.com
(C) 2008 S. Karger AG, Basel

Access to full text and tables of contents, including tentative ones for forthcoming issues: www.karger.com/anm_issues 
No. 3

Original Papers

177 Caseinophosphopeptide-Bound Iron: Protective Effect against Gut Peroxidation

Kibangou, I. (Caen); Bouhallab, S. (Rennes); Bureau, F.; Allouche, S.; Thouvenin, G.; Bouglé, D. (Caen)

181 Effect of Adlay, Buckwheat and Barley on Lipid Metabolism and Aorta Histopathology in Rats Fed an Obesogenic Diet Son, B.K.; Kim, J.Y.; Lee, S.S. (Seoul)

188 Variation of Postprandial PYY P-36 $_{36}$ Response following Ingestion of Differing Macronutrient Meals in Obese Females Helou, N.; Obeid, O.; Azar, S.T.; Hwalla, N. (Beirut)

196 L-Cysteine Down-Regulates SREBP-1C-Regulated Lipogenic Enzymes Expression via Glutathione in HepG2 Cells Bettzieche, A.; Brandsch, C.; Hirche, F.; Eder, K.; Stangl, G.I. (Halle/Saale)

204 In School-Aged Children a Combination of Galacto-Oligosaccharides and Lactobacillus GG Increases Bifidobacteria More than Lactobacillus GG on Its Own Piirainen, L.; Kekkonen, R.A.; Kajander, K.; Ahlroos, T.; Tynkkynen, S.; Nevala, R.; Korpela, R. (Helsinki)

209 Influence of Lys656Asn Polymorphism of Leptin Receptor Gene on Leptin Response Secondary to Two Hypocaloric Diets: A Randomized Clinical Trial

de Luis, D.A.; Aller, R.; Izaola, O.; Gonzalez Sagrado, M.; Conde, R. (Valladolid)

215 Successful Long-Term Treatment of Severe Hypertriglyceridemia by Feedback Control with Lipid Self-Monitoring

Hauenschild, A.; Ewald, N.; Schnell-Kretschmer, H.; Porsch-Oezcueruemez, M.; Kloer, H.-U.; Hardt, P.D. (Giessen)

221 Effect of a Balanced Mixture of Dietary Fibers on Gastric Emptying, Intestinal Transit and Body Weight Bortolotti, M.; Levorato, M.; Lugli, A.; Mazzero, G. (Bologna)

227 Common Predictors of Excessive Adiposity in Children from a Region with High Prevalence of Overweight Basaldúa, N.; Chiquete, E. (Guadalajara)

233 Influence of an Antioxidant Vitamin-Enriched Drink on Pre- and Post-Exercise Lymphocyte Antioxidant System Sureda, A.; Tauler, P.; Aguiló, A.; Cases, N.; Llompart, I.; Tur, J.A.; Pons, A. (Palma de Mallorca)

241 Effects of Simultaneous Intakes of Fish Oil and Green Tea Extracts on Plasma, Glucose, Insulin, C-Peptide, and Adiponectin and on Liver Lipid Concentrations in Mice Fed Low- and High-Fat Diets

Shirai, N. (Tsukuba); Suzuki, H. (Tsukuba/Sakado)

250 Dietary Eicosapentaenoic Acid and Docosahexaenoic Acid Are More Effective than Alpha-Linolenic Acid in Improving Insulin Sensitivity in Rats

Andersen, G.; Harnack, K. (Garching); Erbersdobler, H.F. (Kiel); Somoza, V (Garching)

257 The Official FENS Calendar

258 FENS News

259 IUNS News
No. 4

Original Papers

261 Ramadan Fasting and the GH/IGF-1 Axis of Trained Men during Submaximal Exercise

Bouhlel, E. (Gafsa); Zaouali, M.; Miled, A.; Tabka, Z. (Sousse); Bigard, X. (La Tronche); Shephard, R. (Toronto, Ont.)

267 Relation of Trp64Arg Polymorphism of Beta 3-Adrenergic Receptor Gene to Adipocytokines and Fat Distribution in Obese Patients

de Luis, D.A.; Aller, R.; Izaola, O.; Gonzalez Sagrado, M.; Conde, R. (Valladolid)

272 Dietary Supplements Contribute Substantially to the Total Nutrient Intake in Pregnant Norwegian Women Haugen, M.; Brantsæter, A.L.; Alexander, J.; Meltzer, H.M. (Oslo)

281 Relative Bioavailability of Two Forms of a Novel Water-Soluble Coenzyme Q10

Žmitek, J.; Šmidovnik, A.; Fir, M.; Prošek, M.; Žmitek, K. (Ljubljana); Walczak, J. (Kutno); Pravst, I. (Ljubljana)

288 Bolus Ingestion But Not Regular Consumption of Native or Dealcoholized Red Wine Modulates Selected Immunological Functions of Leukocytes in Healthy Volunteers Ellinger, S. (Aachen/Bonn); Arendt, B.M. (Aachen); Fimmers, R.; Stehle, P.; Spengler, U. (Bonn); Goerlich, R. (Aachen)

296 Association of Serum $\alpha$-Tocopherol, Retinol and Ascorbic Acid with the Risk of Cataract Development Nourmohammadi, I.; Modarress, M.; Khanaki, K.; Shaabani, M. (Tehran)

299 Food Consumption Analysis in Spanish Elderly Based upon the Mini Nutritional Assessment Test

Cuervo, M.; Ansorena, D. (Pamplona); García, A. (Madrid); Astiasarán, I.; Martínez, J.A. (Pamplona)

308 Nutritional Intake of Children and Adolescents with Insulin-Dependent Diabetes Mellitus in Crete, Greece Papadaki, A.; Linardakis, M.; Codrington, C.; Kafatos, A. (Heraklion)

315 Methylenetetrahydrofolate Reductase 677CT Polymorphism and Cobalamin, Folate, and Homocysteine Status in Spanish Adolescents

Al-Tahan, J. (Bonn); Sola, R.; Ruiz, J.R. (Granada); Breidenassel, C. (Bonn); García-Fuentes, M. (Santander); Moreno, L.A. (Zaragoza); Castillo, M. (Granada); Pietrzik, K. (Bonn); González-Gross, M. (Bonn/Granada/Madrid)

322 A Randomized Double-Blind, Placebo-Controlled Study to Establish the Effects of Spirulina in Elderly Koreans Park, H.J.; Lee, Y.J.; Ryu, H.K. (Seoul); Kim, M.H. (Daegu); Chung, H.W.; Kim, W.Y. (Seoul)

329 Effect of Smoking Habit on Circulating Adipokines in Diabetic and Non-Diabetic Subjects

Al Mutairi, S.S.; Mojiminiyi, O.A.; Shihab-Eldeen, A.A.; Al Sharafi, A.; Abdella, N. (Kuwait)

335 Effect of Oral L-Carnitine Administration on Insulin Sensitivity and Lipid Profile in Type 2 Diabetes Mellitus Patients

González-Ortiz, M.; Hernández-González, S.O.; Hernández-Salazar, E. Martínez-Abundis, E. (Guadalajara)

339 The Official FENS Calendar

340 FENS News

341 IUNS News

342 Author Index Vol. 52, 2008

343 Subject Index Vol. 52, 2008

Suppl. 1

Healthy Ageing: The Role of Food, Nutrition and Lifestyle A European Symposium with Outcomes of the Nutri-Senex Project Guest Editors: Elmadfa, I.; Freisling, H. (Vienna) 